\title{
Natural history of a giant abdominal lipoma
}

\author{
Paula S Azevedo, ${ }^{1}$ Bertha Furlan Polegatto, ${ }^{1}$ Luis Felipe M Gradella, ${ }^{2}$ Marina P Okoshi ${ }^{1}$ \\ 1Department of Internal Medicine, Botucatu Medical School, UNESP, Botucatu, Sao Paulo, Brazil; \\ ${ }^{2}$ Department of Radiology, Botucatu Medical School, UNESP, Botucatu, Sao Paulo, Brazil
}

Correspondence to Dr Marina P Okoshi, mpoliti@fmb.unesp.br

\section{DESCRIPTION}

A 79-year-old woman was hospitalised for ischaemic stroke. She had 20 years history of a progressive abdominal enlargement. Ten years earlier abdominal CT had shown a giant abdominal lipoma. At that time she declined surgery. Physical examination revealed aphasia, right hemiparesis and massively enlarged abdominal volume (figure 1). Ischaemic stroke was diagnosed and confirmed by cranial CT. A new abdominal CT (figure 2) with patient in left lateral decubitus revealed a huge hypodense retroperitoneal mass with soft tissue attenuation (A). Right kidney (B) was displaced to the left side of the abdomen and vena cava (C) was in front of the aorta (D). Biopsies from three different areas of the mass showed mature fat cells with no malignant cells. Surgery was refused by the patient and her relatives. The hypothesis of lipoma has been confirmed by the long medical history and laboratory tests. Lipomas are benign tumours and the most common human mesenchymal neoplasia, with an estimated incidence of $10 \% .{ }^{1}$ They often present slow growth and small size. Nevertheless, they can achieve larger sizes. ${ }^{2}$ To be considered a giant lipoma, the tumour has to be at least $10 \mathrm{~cm}$ in diameter or weigh above 1000 g. ${ }^{3}$ Patients with small giant lipoma are usually asymptomatic. However, as the tumour grows, it may cause compression symptoms. The key teaching element of this case relates to the importance of surgically resecting asymptomatic lipomas. Although considered a benign tumour, the massive untreated lipoma has certainly jeopardised the patient quality of life.

\section{Learning points}

- Although being benign tumours, lipomas can grow and reach large sizes.

- As long known, giant lipomas should be surgically ressected.

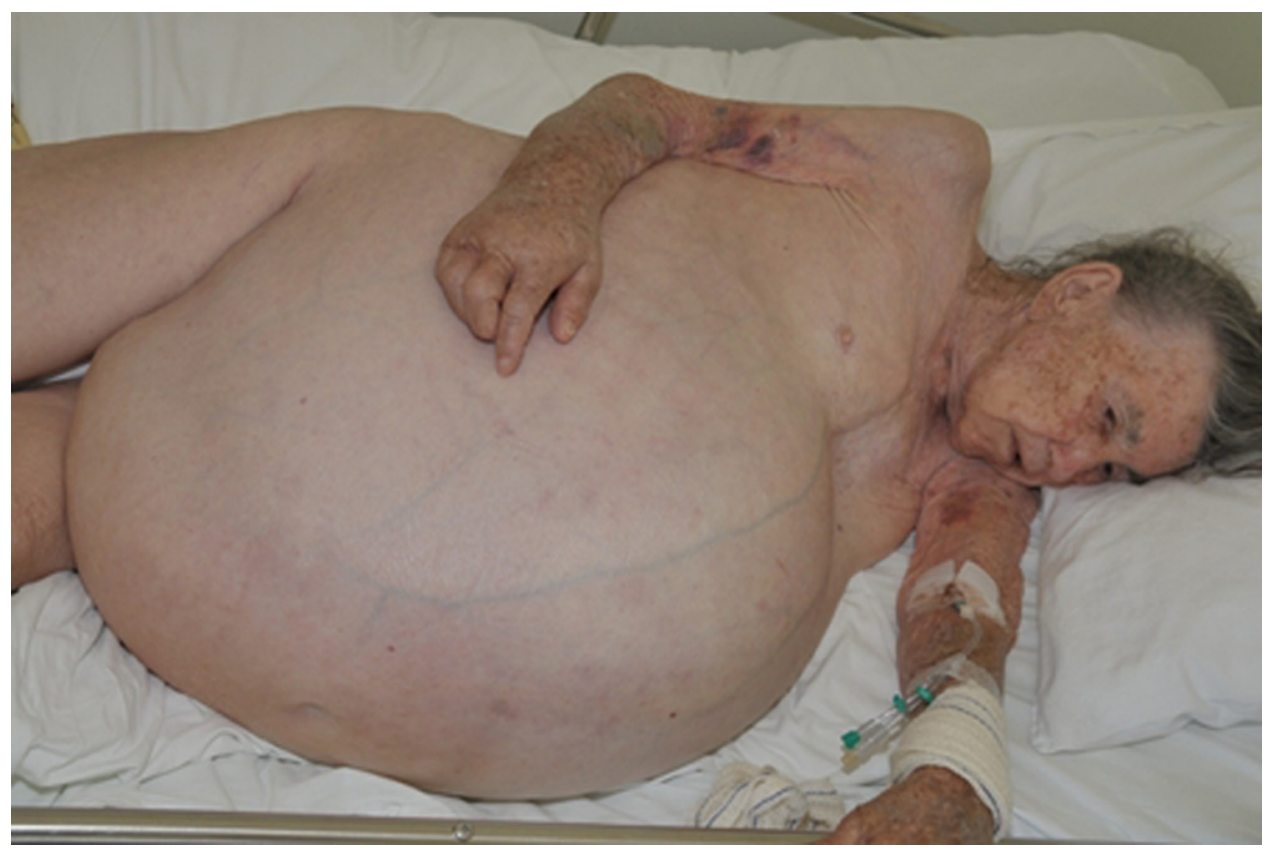

Figure 1 Increased abdominal volume. 


\section{BMJ Case Reports}

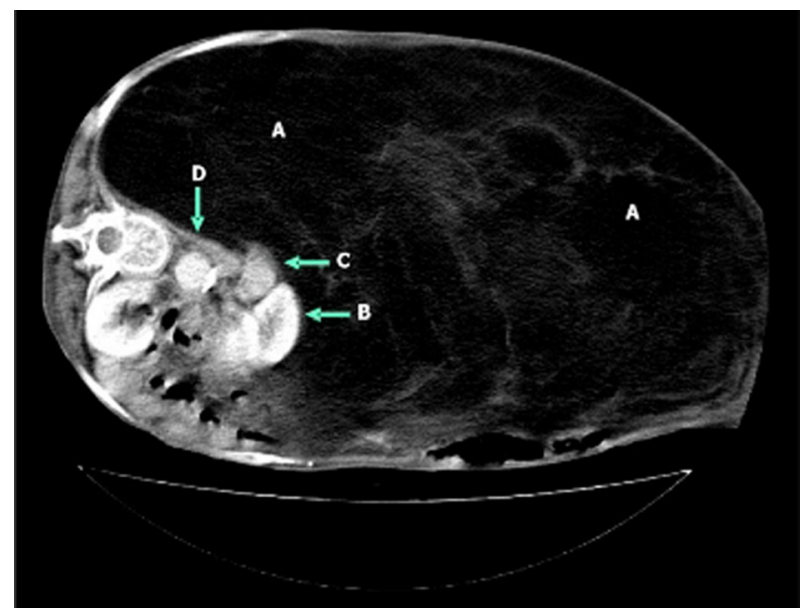

Competing interests None.

Patient consent Obtained.

\section{REFERENCES}

1. Cavazzola LT, Lieberknecht M, Machado AS, et al. Giant lipoma of the spermatic cord. Am J Surg 2009;198:e54-5.

2. Kaczynski J, Hilton J. Giant lipoma of the small bowel associated with perforated ileal diverticulum. BMJ Case Rep 2012;doi:10.1136/ bcr.12.2011.5299.

3. Sanchez MR, Golomb FM, Moy JA, et al. Giant lipoma: case report and review of the literature. J Am Acad Dermatol 1993;28:266-8.

Figure 2 Abdominal CT with patient in left lateral decubitus showing a huge retroperitoneal mass with soft tissue attenuation (A). Right kidney (B) is displaced to the left side of the abdomen, and vena cava (C) is located in front of the aorta (D).

This pdf has been created automatically from the final edited text and images.

Copyright 2012 BMJ Publishing Group. All rights reserved. For permission to reuse any of this content visit http://group.bmj.com/group/rights-licensing/permissions.

BMJ Case Report Fellows may re-use this article for personal use and teaching without any further permission.

Please cite this article as follows (you will need to access the article online to obtain the date of publication).

Azevedo PS, Polegatto BF, Gradella LFM, Okoshi MP. Natural history of a giant abdominal lipoma. BMJ Case Reports 2012;10.1136/bcr.01.2012.5638, Published XXX

Become a Fellow of BMJ Case Reports today and you can:

- Submit as many cases as you like

- Enjoy fast sympathetic peer review and rapid publication of accepted articles

- Access all the published articles

- Re-use any of the published material for personal use and teaching without further permission

For information on Institutional Fellowships contact consortiasales@bmjgroup.com

Visit casereports.bmj.com for more articles like this and to become a Fellow

Keep up to date with all published cases by signing up for an alert (all we need is your email address) http://casereports.bmj.com/cgi/alerts/etoc 